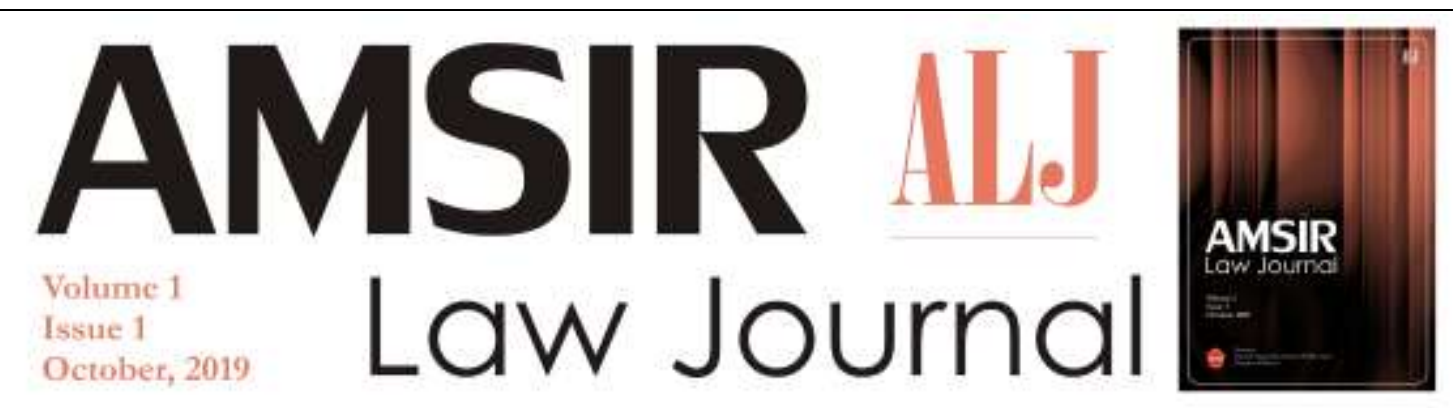

e-issn:

Nationally Accredited Journal, Decree No. .......................

This work is licensed under a Creative Commons Attribution 4.0 International License.

\title{
The State of Notary as a Legal Auditor
}

\section{Dinza Diastami M, ${ }^{1}$ Ahmadi Miru, ${ }^{2}$ Hasbir Paserangi ${ }^{3}$}

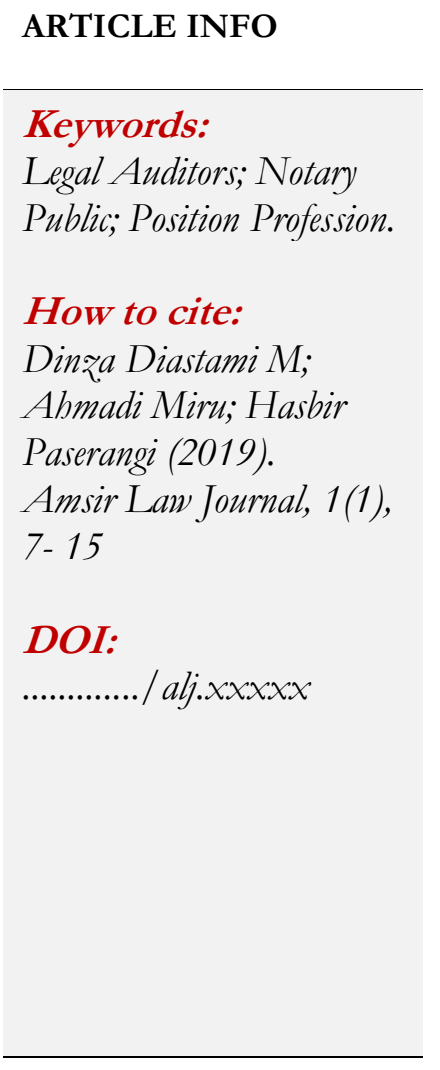

\begin{abstract}
The existence of legal auditors as a certified profession in carrying out legal audits is essential and strategic in developing a legal compliance system in Indonesia. However, statutory regulations specifically in UUJN (regulation of notary position) does not regulate the probibition of a dual notary position as a legal auditor. This study adopts an empirical juridical approach which was conducted in the Special Capital Region of Jakarta. The results of the study showed that there were no statutory provisions regarding the ability of a person who had served as a notary to become a legal auditor. Although, the Notary Position Law and the code of ethics bindthe notary public which do not also probibit a notary from occupying the position of legal auditor. In the case of a notary and a legal auditor, the potential for a conflict of interest is immense. This was based on the consideration a legal auditor which has the duty to examine and/or assess legal issues related to a company, including the validity of authentic deeds made before a notary official.
\end{abstract}

Copyright (C) 2019 ALJ. All rights reserved.

\section{Introduction}

The position of the notary is a public official (Openbare Amtbtenaren) while carrying out the profession, occupying a strategic position in assisting and providing legal certainty for the community. The notary must be able to prevent the occurrence of legal problems in the future through an authentic document which is made including strong and perfect evidence. However, ethical notaries are only mechanical robots that move without souls.

Pengadilan Negeri Sungguminasa, Gowa, Indonesia.

Fakultas Hukum Universitas Hasanuddin, Indonesia.

Fakultas Hukum Universitas Hasanuddin, Indonesia. 
Due adhering to ethics in the notary profession is called a noble profession (Officium Nobile). ${ }^{4}$

The existence of a public notary in the community nowadays is needed. The public needs a notary whose credibility can be trusted, the signature and seal provide strong guarantees and evidence, an impartial expert and a flawless counselor, everything written and determined is genuine. Thus, the need of a public notary, a notary is needed who can carry out the duties in accordance with the provisions of the applicable legislation which is convenient with the Law of Notary Position.

In the current era of globalization, all countries in the world are flocking to conduct major changes for the progress of their respective countries. One of the major changes are conducting free trade between countries. The free trade has the aim to stop or at least reduce the intervention of countries in the field of trade in particular and in the economy in general. All countries which are participating in this free trade are qualified countries accepting the consequences of being able to increase the economic development, because the case is firmly related in the struggle for market share.

The persistent legal formation of an institution (company/organization) audited at this time is a form of efforts to improve existing laws. The context is intended in order to an institution (company/organization) which is audited has a solid foundation of movement which leads to a more responsive attitude towards the establishment of national development. Besides being a protection for an institution (company/organization) which is audited from legal risk, the case could also be an assessment of the extent of compliance of an institution which is audited against laws and regulations as positive law in force in this country, which will ultimately provide a condition of the audited institution (company/ organization) healthily and reliably. ${ }^{5}$

The existence of legal auditors as a certified profession in conducting legal audits is crucial and strategic in developing a legal compliance system in Indonesia. The legal education and auditor training program is essential because those programs are abundant from the public officials of the state administrators (legislative, executive and judiciary) and the private sector even from academics are not respecting, obeying the law when making decisions and managing legal actions. The case happens because decision makers do not understand the existence of legal risks in decision making therefore causing legal problems and even legal disputes in the implementation. ${ }^{6}$

The legal auditor profession has received official recognition from the Director General of Training and Productivity Development of the Ministry of Manpower and Transmigration with Decree No. PEM. 242/LATTAS/XI/2014 on 4 November 2014. The decree regulates the specific standards of the Indonesian legal auditor profession as a reference in developing a work competency certification scheme for legal auditors. The decree forms the basis of legal auditor education organized by the Indonesian Legal Auditor Association (ASAHI) based on competency certification in accordance with the standards adopted by the National Professional Certification Board (BNSP). The establishment of the Indonesian Legal Auditor Professional Certification Institute (LSP

\footnotetext{
Anshori, A.G. (2009). Lembaga Kenotariatan Indonesia; Perspektif Hukum dan Etika. Yogyakarta: UII Press, p. 6.

Halim, Hamzah. (2015). Cara Praktis Memahami dan Menyusun Legal Audit dan Legal Opinion. Jakarta: Prenadamedia Group, p. 16.

6 Profesi Auditor Hukum (JSLG dan ASAHI). http://www.jimlyschool.com/diklat/profesi-auditor-hukum-jslg-danasahi [Accessed: 8 January 2018].
} 
AHI) for the BNSP is licensed on May 27, 2016. Legal auditor certification is marked by the recognition of a Certified Legal Auditor or commonly abbreviated as C.L.A.

However presently, in the statutory regulations and specifically the Notary Position Law does not regulate the prohibition of notary from concurrently serving as a legal auditor, thus further study is needed related to the existence of the legal auditor profession.

\section{Method}

This study used an empirical juridical approach, which is a method or procedure used to solve problems by first examining existing secondary data, thereupon proceed with research on primary data in the field. ${ }^{7}$ The research was conducted in the Special Capital Region of Jakarta (DKI Jakarta). The intended party was the notary in DKI Jakarta. The reason for choosing the place of research was because the notaries who participated in the education and profession of legal auditors were higher than the provinces in Indonesia. Qualitative analytical methods were used with descriptive analytical descriptions.

\section{Discussion}

\subsection{Legal Basis of the Notary Undertaking a Profession as a Legal Auditor}

Legal audit is a process of evaluating data and facts on transactions conducted by a company/an institution (company/organization) which is audited with another party to assess the security level of the company/an institution (company/organization) audited, especially in the case of legal risk aspects which will ultimately endanger the company/ institution (company/organization) assets that is audited and presented in the audit report regarding opinions and suggestions for improvement. ${ }^{8}$

The alteration of ASAHI (Association of Indonesian Legal Auditors), which is contained in Deed No. 24 dated August 21 2014, had been approved by the Ministry of Law and Human Rights of the Republic of Indonesia Number AHU-192 AH.01.06.Tahun 2011.

The legal auditor profession has received official recognition from the Director General of Training and Productivity Development of the Ministry of Manpower and Transmigration with Decree No. PEM. 242/LATTAS/XI/2014 on 4 November 2014. The decree regulates the specific standards of the Indonesian legal auditor profession as a reference in developing a work competency certification scheme for legal auditors. The decree forms the basis of legal auditor education organized by the Indonesian Legal Auditor Association (ASAHI) based on competency certification in accordance with the standards adopted by the National Professional Certification Board (BNSP). The establishment of the Indonesian Legal Auditor Professional Certification Institute (LSP AHI) for the BNSP is licensed on May 27, 2016. Legal auditor certification is marked by the recognition of a Certified Legal Auditor or commonly abbreviated as C.L.A.

According to Mr. Mardianto, who worked as a legal auditor, based on the results of an interview conducted by the author on April 6, 2019, stating that:

"The legal auditor profession is expected to support both good corporate governance in the business nature and good governance in policy making. This is because the concept of a legal auditor starts with legal due diligence. This is because the legal auditor profession is projected to have more coverage than legal due diligence on business contracts and capital markets. However, the legal basis that

\footnotetext{
Soemitro, R.H. (1998). Metodologi Penelitian Hukum. Jakarta: Ghalia Indonesia, p. 10.

Halim, Hamzah. Op.Cit., p. 13-14.
} 
underpins this profession is still unsteady. Ideally, the legal auditor profession is not only supported by decisions those are decision only, but also must go through regulations those are regeling."

The legal basis for the position of the legal profession of auditors is still unsteady. Regarding who can become a legal auditor is not explained in the two regulations, but only regulates the auditor's legal education curriculum. Basically, there is no prohibition for someone who is a notary to become a legal auditor. The prohibition for a notary to concurrently hold a position has been explained specifically in the regulation, such as the prohibition as a civil servant, concurrently serving as a state official, as an advocate, as a leader or employee of a state-owned enterprise, a regionally-owned enterprise or a business entity private.

In order to avoid legal uncertainty in the future, the government requires establish a regulation in the form of a law controlling the legal position of the auditor. Furthermore, Deed No. 24 dated August 21, 2014, ratification from the Ministry of Law and Human Rights Republic of Indonesia Number AHU-192 AH.01.06. 2011 and Decree of the Director General of Training and Productivity Development of the Ministry of Manpower and Transmigration No. KEP.242/LATTAS/XI/2014 on November 4, 2014 are expected as the basis of the auditor's position and considered with legal basis which has mandatory power, namely the law

In addition, the current regulations do not explicitly and specifically regulate the position of legal auditor, so they still need more concrete arrangements, one of the rules are related to obligations, restrictions and anyone who can become legal auditor. Also, the harmonizing relevant laws and regulations require to conduct, such as a Limited Liability Company law to regulate matters in case of a legal audit of a company.

\subsection{Potential Conflicts of Interest in the Case of a Legal Auditor Concurrently as a Notary}

The position of notary and legal auditor is a profession that has a scope of work. If the notary's job mainly composes an authentic deed, then one of the job scopes of the legal auditor is checking the validity of the deeds composed by the notary public. The concurrent notary position as legal auditor in the author's view has a potential to creating conflict of interest in the performance of the duties in each positions. In a variety of literature, there are various kinds of literature related to conflicts of interest. The definition of a conflict of interest refers to a situation that has the potential to undermine the impartiality of a person because of the possibility of a clash between the person's selfinterest and professional interest or public interest. Duncan Williamson defined a conflict of interest as, "A situation in which a person, such as a public official, an employee, or a professional, has a private or personal interest by influencing the purpose and implementation of the duties of the office or organization."

Both of these definitions could explain about a conflict of interest. There are two reasons why a conflict of interest is being an issue and becomes an unethical act, such as:? first, influencing the interests of the public or office for personal financial interests; second, influencing in decision making which aimed at granting the personal interests.

The definition of a conflict of interest varies but generally refers to circumstances where private interests conflict with formal duties/responsibilities. ${ }^{10}$ Conflicts of interest

\footnotetext{
Sulistiyana, D.B. (2016). Pengelolaan Konflik Kepentingan. Jakarta: Direktorat Direktorat Pendidikan dan Pelayanan Masyarakat KPK., p. 5.

$10 \quad$ Ibid. p. 6.
} 
occur when personal interests are mixed with official duties and responsibilities (conflicts of interest occur when the private interests of an employee interferes with or influences, or appear to interfere with or influence their official duties and responsibilities). ${ }^{11}$ There are three of main types of conflicts of interest, namely: ${ }^{12}$

1. Actual conflicts of interest is conflicts of interest that exist between official duties/ responsibilities and personal interests (where a conflict exists between your official duties or responsibilities and your private interests).

2. Perceived conflict of interest is conflict of interest which is seen as mixed with official duties/responsibilities which in fact become a case or not (where it could be seen by others that your private interests could improperly interfere with or influence you in the performance of your official duties or responsibilities, whether or not this is in fact the case).

3. Potential conflict of interest is personal interests mixed with official duties/ responsibilities in the future (where your private interests could interfere with or influence your official duties or responsibilities in the future).

The explanation above can be seen that the position of notary and legal auditor has potential to create a conflict of interest between both position. Notary Public is an official authorized to make an authentic deed and other authorities as referred to in the law in exercising such authority, a notary is prohibited from holding concurrent positions as stipulated in the UUJN. Although, the interdictions of the double position has been regulated within UUJN.

Notary positions are not only specific but also unique, because even if notaries are appointed and dismissed by the minister of law and human rights, notaries are not civil servants which are employees who are part of an employee corps that are structured with a hierarchical working relationship and are paid by the notary government. The notaries receive honoraria from those who use their services or find their own income, thus the notary is only appointed and dismissed by the minister of law and human rights but not in the hierarchy of the ministry of law and thus adjusting that notary is not a public servant. The double position is prohibited by a notary public servant (Article 3 letter $g$ and Article 17 letter e), state official (Article 3 letter g and Article 17 letter d), advocate (Article 17 letter e), leader or employee of a business entity state-owned, not regionally-owned business, or private business entity (Article 17 letter $\mathrm{f}$ ), the official makes a land deed outside the area of the notary's position (Article 17 letter g) a substitute notary (Article 17 letter $\mathrm{h}$ ) or other work that conflicts with religious norms, decency, or propriety which can affect the honor and dignity of a notary position (Article 17 letter i).

The prohibitions for notaries to concurrently hold such positions are aimed at preventing the occurrence of a conflict of interest when exercising their authority as a notary public. The notary's performance as a professional and general official must be neutral, being in the midst, not in favor of one of the independent and independent parties. If a notary holds concurrent positions that are prohibited from being concurrently based on the National Law, the client might be faced a conflict of interest. To prevent this from being applied to a dual position ban in the Law, it is also intended that the notary will remain independent and neutral in carrying out his duties and positions, so that the notary can carry out the obligations to act honestly, thoroughly, independently, impartially, and

11 Procedures for Managing Conflicts of Interest (2012). Professional Standards Command. NSW Police Force, p. 8.

12 Sulistiyana, D.B. Op.Cit., p. 7. 
safeguard the interests of parties related to legal actions (Article 16 paragraph (1) letter a UUJN). ${ }^{13}$

A notary may also not hold concurrent positions as Notohandjo's opinion which requires a legal professional to have a humane, fair, obedient and honest attitude. A notary who does a double position is very difficult for him/her to be fair and honest, there will be a definitely tendency towards one of the parties who consequently becomes unjust and dishonest. ${ }^{14}$ All of the criteria stated above will be very difficult to fulfill if the notary public official still holds a double position which is prohibited by UUJN.

The stipulation consideration of the concurrent positions prohibitions could also harm the general public. The reason is because the notary's mind is not focused between the two positions that he holds, a notary cannot carry out his/her duties professionally. So, in general a notary must hold fast to his/her function, namely, a mediator who must not take sides, not an intermediary, defender, and other position holders outside the notary position.

There is still a notary who violates the double position because this prohibition is only an offense of complaint, the lack of supervision from the supervisory board of sanctions which the sanctions are given is very mild, also because the lack of moral from the notary. The law does regulate sanctions in stages starting from verbal warning, written, honorable dismissal to abnormal but in reality the sanctions for notaries who commit violations to date are mild and can even be said to be non-existent. In addition, among notaries, both members and their management and the legal and human rights department interpret that concurrent positions may be provided as long as there is no aggrieved party who reports to the notary supervisory assembly, so that the tendency of notaries to violate the prohibition becomes even greater.

Likewise, it is also related to the opinion of Syamsudin Manan Sinaga (Director General of AHU) who said that actions against violations of the double position prohibition only apply if there are people who feel disadvantaged. ${ }^{15}$ The person must report to the notary supervisor's panel, thus, the notary can be prosecuted because of the position.

A violation occurred if the result of the double position causes a loss to one of the parties while the double position itself is not considered an offense that deserves to be sanctioned even though in the law is clearly stated that the notary is prohibited from acting as a double position. By holding a double position, a notary means which she/he has committed an offense without seeing whether a party has been injured or not. If seeing the provisions regarding the concurrent position and the authority of the supervisory panel, the violation of the concurrent position is a complaint offense, which is meaning that the violation by notary will not be subject to sanctions if no party feels disadvantaged by reporting to the supervisory assembly.

One of the causes of the existence of a notary who has concurrent position is because the supervisory panel's own function is not required to actively oversee. If there is no party who feels aggrieved who reports formally to the regional assembly, the notary will still be free to concurrently hold a position prohibited by UUJN. Notaries must be more active in supervising and cracking down on notaries who carry out concurrent positions.

13 Ibid. p. 31-32.

14 A. Muhammad. (2016). Etika Profesi Hukum. Bandung: Citra Aditya Bakti, p. 66.

15 Dirjen AHU Melarang Notaris Rangkap Jabatan. http://www.hukumonline.com/berita/baca/holl9429/syamsudinmanan sinaga-dirjen-ahu-notaris-dilarang-rangkap-jabatan. [Accessed: 28 May 2018]. 
Furthermore, a legal auditor is also bound by the Code of Ethics and the Code of Conduct for the Legal Auditor (KE-PP ASAHI Legal Auditor), as follows:

1. Personality of Legal Auditors:

a. Legal auditors are Indonesian citizens who are God-fearing, of high moral integrity, educated and knowledgeable, skilled and responsible and upholding the Pancasila and the 1945 Constitution of the Republic of Indonesia.

b. Legal auditors at the request of every party, whether government agencies, state institutions or institutions, bodies, councils, and commissions of non-state institutions, individuals, legal entities, non-legal entities or other social institutions, must be prepared to audit law without distinguishing social, economic, political, religious, ethnic, and/or other social status.

c. Legal auditors in carrying out their professional duties are not solely to obtain material rewards, but rather to prioritize compliance and legal compliance in accordance with statutory provisions, norms and standards as well as universal best practices.

d. The legal auditor in carrying out his profession must be free and independent and not be affected and influenced by any party, and must maintain and hold a sense of solidarity between fellow professionals.

e. Legal auditors in carrying out their professional duties must be polite to anyone and always maintain the dignity and dignity and nobility of the legal auditor profession as an honorable profession (Officium Nobile).

f. Legal auditors are required to keep secrets regarding matters or various information from the audit/client or other parties which are given based on the trust obtained while carrying out their professional duties, and still must maintain these secrets after the working relationship between the legal auditor and the audit/client ends.

g. Legal auditors are required to maintain and nurture sense of solidarity among professional partners, thus, they cannot conduct legal audits of certain work or cases which have been carried out by other legal auditors based on requests from the same audit/client.

h. Legal auditors in carrying out their professional duties are prohibited from advertising or promoting themselves as Legal auditors, both in writing through print media and online through electronic media.

2. Relationship between Legal Auditor and Audit/Client. Legal auditors in carrying out their duties:

a. must obey and carry out seriously all provisions of the statutory regulations and ASAHI Statutes and by-laws and best practices;

b. must prioritize the interests of the Audit/Client over the personal interests and/ or interests of the group;

c. prohibited to stipulate the terms and/or provisions that limit the freedom of the Audit/Client to give confidence to the professional partners in managing their interests; and

d. prohibited to determine fees for services that exceed the fairness/feasibility limit.

3. Relationship of Legal Auditors and Professional Partners:

a. Relationship between legal auditors is a professional partner relationship based on the principle of kinship with mutual respect, respect and trust.

b. In the event that there are differences of opinion, disputes occur between professional partners, or the existing of professional partners who are 
considered to be contrary to the ASAHI Legal KE-PP auditors, to be submitted to the ASAHI Legal Auditor Ke-PP Assembly for accountability.

Considering at the various forms of regulation which mentioned above can be seen that both the notary and the legal auditor, each of whom has a code of ethics which basically requires that a part of the members of the organization must act professionally, prioritizing aspects of honesty in order to create a responsible attitude. If someone who is a notary and also a legal auditor carrying out their work is obedient and complied with the code of ethics as stipulated in each of these organizations then the fear of a conflict of interest can be avoided.

\section{Conclusion}

There are no rules that regulate the limits regarding the ability of a person who has served as a notary to be a legal auditor however the notary law and the code of conduct that binds a notary public also do not prohibit a notary from occupying the position of legal auditor. Likewise, ratification from the Ministry of Law and Human Rights of the Republic of Indonesia Number AHU-192 AH.01.06.Tahun 2011 and SK Director General of Training and Productivity Development of the Ministry of Manpower and Transmigration with Decree No. KEP.242/LATTAS/XI/2014 on November 4, 2014 which became the legal basis for legal auditors, also did not regulate the prohibition of a notary to become a legal auditor.

In the case of a notary and a legal auditor, the potential for a conflict of interest is very high. This is based on the consideration that a legal auditor has the duty to examine and/or assess legal issues related to a company, including the validity of authentic deeds made before a notary official. Accordingly, the legal position of the auditor must be regulated through regulations that are regels (statutory regulations) and are binding. One of the materials is regulated includes the requirements to be a legal auditor, thus does not cause legal uncertainty in its implementation.

\section{Acknowledgments}

I thank the editorial team of Amsir Law Jurnal for publishing my writing in volume 1, October 2019.

\section{References}

Books with an author:

A. Muhammad. (2016). Etika Profesi Hukum. Bandung: Citra Aditya Bakti.

Anshori, A.G. (2009). Lembaga Kenotariatan Indonesia; Perspektif Hukum dan Etika. Yogyakarta: UII Press.

Halim, Hamzah. (2015). Cara Praktis Memahami dan Menyusun Legal Audit dan Legal Opinion. Jakarta: Prenadamedia Group.

Soemitro, R.H. (1998). Metodologi Penelitian Hukum. Jakarta: Ghalia Indonesia.

Sulistiyana, D.B. (2016). Pengelolaan Konflik Kepentingan. Jakarta: Direktorat Direktorat Pendidikan dan Pelayanan Masyarakat KPK. 
World Wide Web:

Profesi Auditor Hukum (JSLG dan ASAHI).

http://www.jimlyschool.com/diklat/profesi-auditor-hukum-jslg-dan-asahi [Accessed: 8 January 2018].

Dirjen AHU Melarang Notaris Rangkap Jabatan.

http://www.hukumonline.com/berita/baca/holl9429/syamsudin-manan sinagadirjen-ahu-notaris-dilarang-rangkap-jabatan. [Accessed: 28 May 2018].

\section{Conflict of Interest Statement:}

The author declares that the research was conducted in the absence of any commercial or financial relationships that could be construed as a potential conflict of interest.

Copyright (C) 2019 ALJ. All rightsreserved. 